\title{
Food consumption and adipose tissue DDT levels in Mexican women
}

\author{
Consumo de alimentos y niveles de DDT \\ en tejido adiposo de mujeres mexicanas
}

\begin{abstract}
Marcia Galván-Portillo 1
Carlos Jiménez-Gutiérrez 1

Luisa Torres-Sánchez 1

Lizbeth López-Carrillo 1
\end{abstract}

1 Instituto Nacional
de Salud Pública.
Av. Universidad 655,
Cuernavaca, Morelos,
62508 México.
lizbeth@correo.insp.mx

\begin{abstract}
This article analyzes food consumption in relation to levels of DDE (the principal metabolite of DDT) in the adipose tissue of 207 Mexican women residing in States with high and low exposure to DDT. Data on the women's dietary habits and childbearing history were obtained from a personal interview. Adipose tissue DDE levels were measured by gas-liquid chromatography and compared by analysis of variance (ANOVA) and multiple linear regression. Adipose tissue DDE levels increased significantly with age $(p=0.005)$ and residence in coastal areas $(p=$ 0.002) and non-significantly with the consumption of onion, cauliflower, prickly pear, squash blossoms, sweet corn, broad beans, chili pepper sauce, ham, and fish. Even so, during breastfeeding there was a non-significant reduction in these levels. The findings suggest that certain foods serve as vehicles for DDE residues and confirm that breastfeeding is a mechanism for the elimination of this insecticide, which accumulates over the years in the human body.
\end{abstract}

Key words DDT; Adipose Tissue; Diet; Endocrine Disruptors

Resumen En este trabajo se presenta el consumo de alimentos en relación a los niveles de DDE (principal metabolito del DDT) en tejido adiposo de 207 mujeres Mexicanas residentes en estados de alta y baja exposición a DDT. La información acerca de los hábitos dietéticos y la historia reproductiva de cada una de las participantes se indagaron mediante una entrevista personal. Los niveles de DDE en el tejido adiposo se determinaron por medio de cromatografía de gas-líquido y se compararon por medio de análisis de varianza (ANOVA) y de regresión lineal múltiple. Los niveles de DDE en tejido adiposo se incrementaron significativamente de acuerdo a la edad ( $p=0.005)$ y al hecho de residir en zonas costeras $(p=0,002) y$, de manera no significativa, con el consumo de: cebolla, coliflor, nopal, flor de calabaza, elote, habas, salsas preparadas con chile, jamón y pescado. Asimismo, el aumento en los meses de lactancia representó una reducción no significativa de estos niveles. Los hallazgos de este trabajo sugieren que cierto tipo de alimentos son vehículos de residuos de DDE, así mismo, confirman que la lactancia es un mecanismo de eliminación de dicho insecticida y que éste se acumula a través de los años en el organismo humano.

Palabras clave DDT; Tejido Adiposo; Dieta; Desreguladores Endócrinos 


\section{Introduction}

DDT, 1,1,1-trichloro-2,2-bis(4-chlorophenyl) ethane, is a synthetic organochlorine used both in agriculture and vector control. The main routes by which it enters the body are through the skin and the gastrointestinal tract, after which it circulates by binding to blood lipids and is deposited in the adipose tissue. The most efficient pathway for its elimination is through maternal milk (Murphy, 1986), reaching a half life of 17 to 22 months, depending on the metabolite analyzed (DDE and DDT, respectively) (López-Carrillo et al., 2001).

Damage from exposure to DDT has been documented principally in animals and human populations undergoing occupational and accidental exposure (Kavlock et al., 1996). However, damage to health from low and continuous exposure is reason for investigation, especially as relates to the compound's capacity to disrupt the endocrine system. Due to its estrogenic activity, interest has focused on its possible relationship to the development of estrogen-dependent tumors, where evidence to date has not been conclusive (López-Carrillo, in press). In addition, based on its anti-androgenic activity, it has been suggested that DDT could effect the male reproductive function, principally by interfering with the hypothalamic-hypophyseal axis (Sharpe, 1995; Toppari et al., 1996).

Although its use was prohibited in most countries of the world, in Mexico DDT was used since the 1940s with an irregular downward trend until 1988 and virtually no use at present (López-Carrillo et al., 1996). Its most widespread use has been in programs to combat malaria, especially in the Mexico's coastal areas, where the disease is endemic and which were considered areas with high exposure to DDT until 1997 (Centro Nacional de Salud Ambiental, 2000).

Various studies in Mexico identified DDT and its metabolites in human biological samples from occupationally-exposed individuals and those not exposed to pesticides, in blood (López-Carrillo et al., 1997; Waliszewski et al., 2000), tissue (Albert et al., 1980; López-Carrillo et al., 1999; Redetzke et al., 1983; Waliszewski et al., 1995), and milk (Albert et al., 1981; Terrones et al., 2000; Torres-Arreola, 1999; Viveros \& Albert, 1990). Due to its lypophilic properties, DDT has been found in the breast milk of populations in endemic malaria areas at higher concentrations than the maximum daily dose accepted by the World Health Organization. High levels have been shown in both workers and population groups not occupationally exposed in malaria areas in Veracruz (Centro Nacional de Salud Ambiental, 2000).

Intake of foods containing DDT (dichlorodiphenyltrichloroethane) residues constitutes a source of human exposure to this insecticide. Specifically, plasma DDT levels have been associated with fish consumption (Asplund et al., 1994; Hovinga et al., 1992; Kearney et al., 1999), while breast milk DDT levels are related to the consumption of fat-rich red meat (Devoto \& Kohlmeier, 1998), fish (Dagher et al., 1999; López-Carrillo et al., 1996), chicken (Devoto \& Kohlmeier, 1998), milk, and some fruits and tubers (Schinas et al., 2000).

This study analyzes food consumption as related to levels of DDE (the main metabolite of DDT) in the adipose tissue of Mexican women residing in States with high and low exposure to DDT.

\section{Material and methods}

During March 1994 and April 1996 a hospital case-control study was conducted on breast cancer and DDT exposure in Mexico. As part of this study, 207 women were identified with benign breast disease from which a sample of adipose tissue surrounding the lesion was obtained to histologically rule out the presence of breast cancer before receiving treatment (López-Carrillo et al., 1997).

The women were identified in three tertiary hospitals, two of which belonging to the Secretariat of Health (National Cancer Institute, GEA-González General Hospital) and one to the Social Security System (PEMEX Picacho). They resided in the coastal States of Chiapas, Michoacán, Oaxaca, and Veracruz, as well as in the Federal District and the States of México, Hidalgo, Morelos, Guanajuato, and Puebla, located in the central area of the country. The former States, where malaria is endemic, are classified as having high exposure to DDT, while exposure levels are lower in the latter (Centro Nacional de Salud Ambiental, 2000; López-Carrillo et al., 1996).

Data on participants' childbearing history and dietary habits were obtained through a personal interview. Each woman was measured and weighed to estimate the Body Mass Index (Quetelet Index, kg/m²).

Adipose tissue DDE levels were measured by gas-liquid chromatography, according to the protocol recommended by the United States Environmental Protection Agency (EPA, 1981). Concentrations were reported in lipid base (ng/g). 


\section{Dietary information}

Food frequency data were compiled (for dairy products, fruits, vegetables, meat, processed meat, fish, soft drinks, candy, and grains) using a validated questionnaire (Hernández-Ávila et al., 1998).

Frequency of daily consumption was measured for each type of food based on the size of a defined portion. Options for answers included 10 categories, ranging from "never" to "6 times a day". Consumption of fruits and vegetables was adjusted according to their availability on the market over the course of the year.

\section{Statistical analysis}

Mean DDE levels in adipose tissue were compared according to selected characteristics of the women as well as food consumption, using analysis of variance (ANOVA). Multiple linear regression models were estimated to identify the principal predictors of adipose tissue DDE levels. Statistical analysis used Stata 6.0 (Stata Corporation, 1999).

\section{Results}

Table 1 shows DDE levels according to selected variables for the 207 study participants. Women over 44 years of age showed the highest mean DDE level (841.23ng/g), significantly greater than for women 26-34 years old (320.28ng/g) and marginally significant as compared to women 25 years and younger (350.47ng/g).

DDE levels decreased with duration of breastfeeding, although the tendency test was not significant (reported in Table $3 ; \mathrm{p}=0.288$ ). On the other hand, a highly significant difference was obtained by comparing DDE levels for women residing in endemic malaria areas (on the coast) with those of women residing in central Mexico $(p=0.002)$. No pattern of DDE levels was observed either for parity or Quetelet Index.

Adipose tissue DDE levels were higher (but not significantly, according to ANOVA) among women who reported consuming onion, cauliflower, prickly pear, squash blossoms, sweet corn, broad beans, chili pepper sauce, ham, and fish as compared to those who did not routinely eat these foods (Table 2).

Table 3 shows the effect of breastfeeding, age, and place of residence (high exposure to DDT on the coast versus low exposure in central Mexico) on DDE levels in adipose tissue. A
Table 1

DDE levels according to selected variables.

\begin{tabular}{|c|c|c|c|}
\hline \multirow[t]{2}{*}{ Variables } & \multirow[t]{2}{*}{$\mathrm{n}$} & \multicolumn{2}{|c|}{ DDE (ng/g) } \\
\hline & & $X^{1}$ & $95 \% \mathrm{Cl}$ \\
\hline \multicolumn{4}{|l|}{ Age } \\
\hline$<25$ & 59 & 350.47 & $221.22-555.24$ \\
\hline $26-34$ & 48 & 320.28 & $202.70-506.06$ \\
\hline $35-43$ & 50 & 679.87 & $428.99-1,077.46$ \\
\hline$\geq 44$ & 50 & $841.23^{*}$ & $541.96-1,305.76$ \\
\hline$p$ value (ANOVA) & & 0.005 & \\
\hline \multicolumn{4}{|l|}{ Parity (no. children) } \\
\hline 0 & 66 & 450.92 & $295.62-687.81$ \\
\hline $1-3$ & 88 & 558.00 & $401.46-775.58$ \\
\hline$\geq 4$ & 53 & 465.35 & $280.78-771.27$ \\
\hline$p$ value (ANOVA) & & 0.698 & \\
\hline \multicolumn{4}{|c|}{$\begin{array}{l}\text { Total duration of } \\
\text { breastfeeding (months) }\end{array}$} \\
\hline 0 & 19 & 921.92 & $479.66-1,771.97$ \\
\hline $1-6$ & 35 & 455.53 & $271.80-763.44$ \\
\hline $7-12$ & 28 & 517.51 & $299.42-894.45$ \\
\hline $14-54$ & 59 & 471.40 & $285.49-778.38$ \\
\hline$p$ value (ANOVA) & & 0.446 & \\
\hline \multicolumn{4}{|c|}{ Quetelet Index $\left(\mathrm{kg} / \mathrm{m}^{2}\right)$} \\
\hline$\leq 21.50$ & 51 & 304.46 & $165.37-560.56$ \\
\hline $21.60-24.41$ & 51 & 571.89 & $403.50-810.55$ \\
\hline $24.42-26.92$ & 52 & 659.89 & $425.04-1,024.49$ \\
\hline$>26.93$ & 50 & 514.72 & $337.43-785.17$ \\
\hline$p$ value (ANOVA) & & 0.098 & \\
\hline \multicolumn{4}{|l|}{ Area of residence } \\
\hline Coast 3 & 56 & 883.00 & $529.40-1,472.80$ \\
\hline Central Mexico 4 & 149 & 399.22 & $311.03-512.42$ \\
\hline$p$ value (ANOVA) & & 0.002 & \\
\hline
\end{tabular}

1 Geometric mean.

2 Nulliparous women were excluded from the analysis.

3 Includes States of Chiapas, Michoacán, Oaxaca, and Veracruz.

4 Includes Federal District and States of México, Hidalgo, Morelos,

Guanajuato, and Puebla.

* $p=0.039 ; \geq 44$ vs. $26-34$ years, Scheffe.

$\star p=0.054 ; \geq 44$ vs. $<25$ years, Scheffe.

decrease of $0.005 \mathrm{ppb}$ of DDE in adipose tissue was obtained per month of breastfeeding and a significant increase of $0.027 \mathrm{ppb}$ per year of age. Women residing on the coast had a significant adipose tissue DDE increase of 0.7 ppb, compared to women residing in central States.

Consumption of some foods was related in non-significant fashion to adipose tissue DDE levels, independently of breastfeeding, age, and State of residence. As shown in Table 4, the lowest regression coefficients were related to 
Table 2

DDE levels according to selected foods.

\begin{tabular}{|c|c|c|c|c|}
\hline \multirow{2}{*}{$\begin{array}{l}\text { Foods } \\
\text { (portions/day) }\end{array}$} & \multirow[t]{2}{*}{$\mathbf{n}$} & \multicolumn{3}{|c|}{ DDE (ng/g) } \\
\hline & & $\mathrm{X}^{1}$ & SD & $95 \% \mathrm{Cl}$ \\
\hline \multicolumn{5}{|l|}{ Onion } \\
\hline No & 18 & 415.10 & 9.40 & $136.18-1,265.33$ \\
\hline Yes & 187 & 511.45 & 5.05 & 404.69-646.39 \\
\hline \multicolumn{5}{|l|}{ Cauliflower } \\
\hline No & 70 & 459.47 & 5.12 & $311.22-678.35$ \\
\hline Yes & 137 & 518.40 & 5.48 & $388.89-691.05$ \\
\hline \multicolumn{5}{|l|}{ Prickly pear } \\
\hline No & 19 & 390.10 & 13.46 & $111.42-1,365.84$ \\
\hline Yes & 186 & 505.50 & 4.77 & $403.20-633.78$ \\
\hline \multicolumn{5}{|l|}{ Squash blossom } \\
\hline No & 78 & 438.98 & 6.04 & $292.61-658.56$ \\
\hline Yes & 129 & 536.91 & 4.95 & $406.34-709.42$ \\
\hline \multicolumn{5}{|l|}{ Sweet corn } \\
\hline No & 17 & 458.92 & 3.04 & $259.06-812.97$ \\
\hline Yes & 190 & 501.30 & 5.58 & $391.96-641.13$ \\
\hline \multicolumn{5}{|l|}{ Broad beans } \\
\hline No & 45 & 417.60 & 3.23 & $293.49-594.20$ \\
\hline Yes & 162 & 522.52 & 5.99 & $395.78-689.86$ \\
\hline \multicolumn{5}{|c|}{ Chili pepper sauce } \\
\hline No & 24 & 472.42 & 8.76 & $188.96-1181.12$ \\
\hline Yes & 183 & 501.08 & 4.99 & $396.37-633.47$ \\
\hline \multicolumn{5}{|l|}{ Ham } \\
\hline No & 64 & 451.29 & 6.16 & $286.49-710.87$ \\
\hline Yes & 143 & 519.95 & 5.01 & $398.29-678.78$ \\
\hline \multicolumn{5}{|l|}{ Fish } \\
\hline No & 51 & 359.23 & 6.68 & 210.54-612.94 \\
\hline Yes & 156 & 553.64 & 4.89 & $430.67-711.72$ \\
\hline
\end{tabular}

1 Geometric mean.

Table 3

Effect of breastfeeding, age, and State of residence on adipose tissue DDE levels.

\begin{tabular}{|c|c|c|}
\hline Variables & $\beta$ & $\mathrm{p}$ \\
\hline Total duration of breastfeeding (months) ${ }^{1}$ & -0.005 & 0.288 \\
\hline Age (years) ${ }^{2}$ & 0.027 & 0.003 \\
\hline Area of residence 3 (coast 4 versus central Mexico 5 ) & 0.704 & 0.007 \\
\hline
\end{tabular}

R2 of model $=0.0844$.

1 Adjusted by age and area of residence.

2 Adjusted by total breastfeeding and State of residence.

3 Adjusted by total breastfeeding and age.

4 States with high exposure to DDT.

5 States with low exposure to DDT. consumption of onion, beans, and chili pepper sauce $(\beta=0.01, \beta=0.04$, and $\beta=0.06$, respectively), followed by prickly pear, broad beans, and sweet $\operatorname{corn}(\beta=0.12, \beta=0.13$, and $\beta=0.24$, respectively). The greatest impact on adipose tissue DDT levels was observed with the consumption of ham $(\beta=0.54)$, squash blossoms $(\beta=0.82)$, fish $(\beta=0.85)$, and cauliflower $(\beta=$ $0.94)$.

\section{Discussion}

This study's findings suggest that certain types of foods are vehicles for DDE residues and confirm that breastfeeding is a mechanism for the elimination of this insecticide, which accumulates over the years in the human body.

Due to the lack of data on the impact of dietary habits in Mexico in relation to DDE levels in human adipose tissue, the current results provide preliminary information on the importance of specific food consumption that should be interpreted with caution since they derive from a secondary analysis of data from lowermiddle class women. Thus the results cannot be generalized to all Mexican women.

Adipose tissue DDT levels in participating women are consistent with the volumes of DDT sprayed in Mexico, which have varied over time according to the country's geographic sub-regions. Note that the States of Veracruz and Tabasco, located on the Gulf of Mexico, have been subjected to the heaviest spraying of DDT, followed by the States of Chiapas, Oaxaca, Guerrero, Michoacán, and Sinaloa, all located on the Pacific Coast.

In contrast to the availability of information on DDT spraying in anti-malaria campaigns in Mexico, data are scarce on dietary exposure to this compound. DDT levels have been documented independently in serum (López-Carrilloet al., 1997; Waliszewski et al., 2000), adipose tissue (Albert et al., 1980; López-Carrillo et al., 1999; Redetzke et al., 1983; Waliszewski et al., 1995), and breastmilk (Albert, 1981; Albert et al., 1981; Terrones et al., 2000; Torres-Arreola et al., 1999; Viveros \& Albert, 1990) in addition to residues of this insecticide in butter (Waliszewski et al., 1996a, 1997) and cow's milk (Waliszewski et al., 1996b, 1997), which in general show a wide environmental spread of DDT in Mexico.

Recently, consumption of salted jerky and fish was significantly associated with DDE levels in breastmilk among women residing in Mexico City (Torres-Arreola et al., 1999). It is possible that consumption of these foods also 
increase DDE levels in adipose tissue and serum, since these levels are maintained in equilibrium with DDE levels in breastmilk (Travis et al., 1988).

In line with other international studies (Asplund et al., 1994; Devoto et al., 1998; Kearney et al., 1999; Mussalo-Rauhamaa et al., 1984) consumption of fish and ham is highly related to DDE levels in the adipose tissue of Mexican women. Among other foods that have been identified, onion, squash blossoms, broad beans, beans, prickly pear, chili pepper sauce, and sweet corn contain the compound. Since these foods do not contain lipids, chemical assays are needed to determine which mechanisms may be responsible for the presence of DDE in them.

\section{Acknowledgments}

The original study providing the basis for the data analyzed here was submitted for approval by the Research Ethics Committee of the Mexican National Institute of Public Health. This study was partially supported by grants from the Consejo Nacional de Ciencia y Tecnología (CONACYT, 31034-M).

\section{References}

ALBERT, L., 1981. Residuos de plaguicidas organoclorados en leche materna y riesgo para la salud. Boletín de la Oficina Sanitaria Panamericana, 91: 15-29.

ALBERT, L.; MENDEZ, F.; CEBRIAN, M. \& PORTALES, A., 1980. Organochlorine pesticide residues in human adipose tissue in Mexico: Results of a preliminary study in three Mexican Cities. Archives of Environmental Health, 35:262-269.

ALBERT, L.; VEJA, P. \& PORTALES, A., 1981. Organochlorine pesticide residues in human milk samples from Comarca Lagunera, Mexico 1976. Pesticide Monitoring Journal, 15:135-138.

ASPLUND, L.; SVENSSON, B. G.; NILSSON, A.; ERIKSSON, U.; JANSSON, B.; JENSEN, S.; WIDEQVIST, U. \& SKERFVING, S., 1994. Polychlorinated biphenyls, 1,1,1-trichloro-2,2-bis(p-chlorophenyl) ethane (p,p'-DDT) and 1,1-dichloro-2,2-bis(pchlorophenyl)-ethylene (p,p'-DDE) in human plasma related to fish consumption. Archives of Environmental Health, 49:477-486.

CENTRO NACIONAL DE SALUD AMBIENTAL, 2000. Centro de Vigilancia Epidemiológica. Situación Actual de la Malaria y el Uso de DDT en México. México, DF: Secretaría de Salud.
Table 4

Effect of selected foods on adipose tissue DDE levels.

\begin{tabular}{lccc}
\hline Foods (portions/day) & $\beta^{\star}$ & $95 \% \mathrm{Cl}$ & $\mathbf{R}^{2}$ \\
\hline Onion & 0.01 & $-0.59-0.63$ & 0.0856 \\
Cauliflower & 0.94 & $-0.65-2.54$ & 0.0906 \\
Prickly pear & 0.12 & $-0.81-1.06$ & 0.0821 \\
Squash blossoms & 0.82 & $-0.49-2.14$ & 0.0912 \\
Sweet corn & 0.24 & $-0.63-1.12$ & 0.0857 \\
Beans & 0.04 & $-0.44-0.53$ & 0.0845 \\
Broad beans & 0.13 & $-0.22-0.49$ & 0.0869 \\
Chili pepper sauce & 0.06 & $-0.30-0.42$ & 0.0848 \\
Ham & 0.54 & $-0.56-1.65$ & 0.0887 \\
Fish & 0.85 & $-1.10-2.79$ & 0.0877 \\
\hline
\end{tabular}

* Adjusted by total duration of breastfeeding (months), age (years), and area of residence (coast versus central Mexico).
DAGHER, S. M.; TALHOUK, R. S.; NASRALLAH, S. S.; TANNOUS, R. I. \& MROUEH S. M., 1999. Relationship of dietary intake to DDE residues in breast milk of nursing mothers in Beirut. Food Additives and Contaminants, 16:307-312.

DEVOTO, E. \& KOHLMEIER, L., 1998. Some dietary predictors of plasma organochlorine concentrations in an elderly German population. Archives of Environmental Health, 53:147-162.

EPA (Environmental Protection Agency), 1981. Manual of Analytical Methods for the Analysis of Pesticides in Human and Environmental Samples. Washington, DC: EPA.

HERNANDEZ-AVILA, M.; ROMIEU, I.; PARRA, S.; HERNANDEZ-AVILA, J.; MADRIGAL, H. \& WILLETT, W., 1998. Validity and reproducibility of food frequency questionnaire to assess dietary intake of women living in Mexico City. Salud Pública de México, 39:133-140.

HOVINGA, M. E.; SOWERA, M. F. \& HUMPHREY, E. B., 1992. Historical changes in serum PCB and DDT levels in an environmentally-exposed cohort. Archives of Environmental Contamination and Toxicology, 22:362-366.

KAVLOCK, R. J.; DASTON, G. P.; DEROSA, C.; FEN- 
NER-CRISP, P.; GRAY, E. L.; KAATTARI, S.; LUCIER, G.; LUSTER, M.; MAC, M. J.; MACZKA, C.; MILLER, R.; MOORE, J.; ROLLAND, R.; SCOTT, G.; SHEEHAN, D. M.; SINKS, T. \& TILSON, H. A., 1996. Research needs for the risk assessment of health and environmental effects of endocrine disruptors: A report of the U.S. EPA-sponsored workshop. Environmental Health Perspectives, 104:715-740.

KEARNEY, J. P.; COLE, D. C.; FERRON, L. A. \& WEBER, J. P., 1999. Blood PCB, p,p-DDE, and mirex levels in Great Lakes fish and waterfowl consumers in two Ontario communities. Environmental Research, 80(Sup. 2):S138-S149.

LOPEZ-CARRILLO, L., in press. Human health cancer. In: Global Assessment on the State-of-the-Science of Endocrine Disruptors. Nairobi: United Nations Environment Programme/International Labour Organization/World Health Organization.

LOPEZ-CARRILLO, L.; BLAIR, A.; LOPEZ-CERVANTES, M.; CEBRIAN, M.; RUEDA, C.; REYES, R.; MOHAR, A. \& BRAVO, J., 1997. Dichlorodiphenyltrichloroethane serum levels and breast cancer risk: A case-control study from Mexico. Cancer Research, 57:3728-3732.

LOPEZ-CARRILLO, L.; TORRES-ARREOLA, L.; TORRES-SANCHEZ, L.; ESPINOSA-TORRES, F.; JIMENEZ, C.; CEBRIAN, M.; WALISZEWSKI, S. \& SALDATE, O., 1996. Is DDT use a public health problem in Mexico? Environmental Health Perspectives, 104:584-588.

LOPEZ-CARRILLO, L.; TORRES-SANCHEZ, L.; LOPEZ-CERVANTES, M.; BLAIR, A.; CEBRIAN, M. \& URIBE, M., 1999. The adipose tissue to serum dichlorodiphenyldichloroethane (DDE) ratio: Some methodological considerations. Environmental Research, 81:142-145.

LOPEZ-CARRILLO, L.; TORRES-SANCHEZ, L.; MOLINE, J.; IRELAND, K. \& WOLFF, M., 2001. Breastfeeding and serum DDT levels among Mexican childbearing aged women. A pilot study. Environmental Research, 87:131-135.

MURPHY, S. D., 1986. Toxic effects of pesticides. In: Casarett \& Doull's Toxicology. The Basic Science of Poisons (C. D. Klaassen, M. O. Amdur \& J. Doull, ed.), pp. 543-547, 3rd Ed., New York: MacMillan Publishing.

MUSSALO-RAUHAMAA, H.; PYYSALO, H. \& MOILANEN, R., 1984. Influence of diet and other factors on the levels of organochlorine compounds in human adipose tissue in Finland. Journal of Toxicology and Environmental Health, 13:689-704.

REDETZKE, K. A.; GONZALEZ, A. A. \& APPLEGATE, H. G., 1983. Organochlorine pesticides in adipose tissue of persons from Cuidad Juarez, Mexico. Journal of Environmental Health, 46:25-27.

SCHINAS, V.; LEOTSINIDIS, M.; ALEXOPOULOS, A.; TSAPANOS, V. \& KONDAKIS, X. G., 2000. Organochlorine pesticide residues in human breast milk from southwest Greece: Associations with weekly food consumption patterns of moth- ers. Archives of Environmental Health, 55:411-417.

SHARPE, R. M., 1995. Another DDT connection. Nature, 375:538-539.

TERRONES, M. C.; LLAMAS, J.; JARAMILLO, F.; ESPINO, M. G. \& LEON, J. S., 2000. DDT and related pesticides in maternal milk and other tissues of healthy women at term pregnancy. Ginecología y Obstetricia de México, 68:97-104.

TOPPARI, J.; LARSEN, J. C.; CHRISTIANSEN, P.; GIWERCMAN, A.; GRANDJEAN, P.; GUILLETTE, L. J.; JEGOU, B.; JENSEN, T. K.; JOUANNET, P.; KEIDING, N.; LEFFERS, H.; MCLACHLAN, J. A.; MEYER, O.; MULLER, J.; RAJPERT-DE MEYTS, E.; SCHEIKE, T.; SHARPE, R.; SUMPTER, J. \& SKAKKEBAEK, N. E., 1996. Male reproductive health and environmental xenoestrogens. Environmental Health Perspectives, 104(Sup. 4):741-803.

TORRES-ARREOLA, L.; LOPEZ-CARRILLO, L.; TORRES-SANCHEZ, L.; CEBRIAN, M.; RUEDA, C.; REYES, R.; LOPEZ-CERVANTES, M., 1999. Levels of dichloro-diphenyl-trichloroethane (DDT) metabolites in maternal milk and their determinant factors. Archives of Environmental Health, 54:124-129.

TRAVIS, C. C.; HATTEMER'FREY, H. A. \& ARMS, A. D., 1988. Relationship between dietary intake of organic chemicals and their concentrations in human adipose tissue and breast milk. Archives of Environmental Contamination and Toxicology, 17:473-478.

VIVEROS, A. S. \& ALBERT, L. A., 1990. Estudios sobre plaguicidas en leche materna en México. Ciencia y Desarrollo, 16:83-90.

WALISZEWSKI, S.; AGUIRRE, A.; INFANZON, R. M. \& SILICEO, J., 2000. Carry-over of persistent organochlorine pesticides through placenta to fetus. Salud Pública de México, 42:384-390.

WALISZEWSKI, S.; PARDIO, V.; WALISZEWSKI, K. N.; CHANTIRI, J. N.; AGUIRRE, A. A.; INFANSON, R. M. \& RIVERA, J., 1997. Organochlorine pesticide residues in cow's milk and butter in Mexico. Science of the Total Environment, 208:127-132.

WALISZEWSKI, S.; PARDIO, V.; WALISZEWSKI, K. N.; CHANTIRI, J. N. \& INFANSON, R. M., 1996a. Levels of organochlorine pesticides in Mexican butter. Journal of AOAC International, 79:784-786.

WALISZEWSKI, S.; PARDIO, V.; WALISZEWSKI, K. N.; CHANTIRI, J. N.; INFANSON, R. M. \& RIVERA, J., 1996b. Detection of some organochlorine pesticides in cow's milk. Food Additives and Contamination, 13:231-235.

WALISZEWSKI, S.; PARDIOS-SEDAS, V. T.; CHANTIRIPEREZ, J. N.; INFANZON-RUIZ, R. M. \& RIVERA, J., 1995. Evaluación de los niveles de DDT y HCH en el tejido adiposo de algunas personas fallecidas en el estado de Veracruz, México. Revista Internacional de Contaminación Ambiental, 11:87-93.

Submitted on 5 February 2001

Final version resubmitted on 6 August 2001

Approved on 27 September 2001 